\title{
PENGARUH PANDEMI COVID-19 TERHADAP BUDAYA BOTRAM DAN MAKAN LALAPAN PADA MAHASISWA ITB SUKU SUNDA ASAL DAERAH TASIKMALAYA, JAWA BARAT
}

\author{
M. Alvin Syukriant \\ Institut Teknologi Bandung \\ msyukriant@gmail.com \\ Muhammad Fairuziko Nurrajab \\ Institut Teknologi Bandung \\ Fairuz.ziko75@gmail.com \\ Rumaisa Hilwa Maulida \\ Institut Teknologi Bandung \\ rumaisahw25@gmail.com
}

\begin{abstract}
ABSTRAK
Adanya pandemi COVID-19 mengakibatkan mayoritas sektor di Indonesia harus terkena dampaknya. Salah satunya dalam sektor budaya, khususnya budaya masyarakat sunda mengenai budaya botram dan makan lalapan. Penelitian ini dilakukan untuk mengetahui pengaruh pandemi COVID-19 terhadap budaya botram dan makan lalapan pada masyarakat sunda yang tinggal di daerah Tasikmalaya. Target penelitian ini adalah mahasiswa ITB yang tinggal di daerah Tasikmalaya dan merupakan masyarakat sunda. Penelitian ini dilakukan dengan metode penelitian melalui studi literatur dan survei online. Hasil penelitian ini menunjukan terdapat penurunan jumlah botram yang cukup signifikan pada saat pandemi berlangsung. Sementara itu, budaya makan lalapan tidak memiliki perubahan yang signifikan sehingga didapatkan kesimpulan bahwa pandemi tidak mempengaruhi kebiasaan masyarakat sunda dalam konsumsi lalapan.
\end{abstract}

Kata kunci: botram; makan lalapan; masyarakat sunda; pandemi COVID-19; Tasikmalaya

\begin{abstract}
The COVID-19 pandemic has affected the majority of sectors in Indonesia. One of them is in the cultural sector, especially the culture of the Sundanese community regarding botram culture and eating lalapan. This research was conducted to determine the effect of the COVID-19 pandemic on botram culture and fresh vegetables in the Sundanese people living in the Tasikmalaya area. The target of this research is ITB students who live in the Tasikmalaya area and are Sundanese people. This research was conducted using research methods through literature studies and online surveys. The results of this study indicate that there is a significant decrease in the amount of botram during the pandemic. Meanwhile, the culture of lalapan does not have a significant change, so it can be concluded that the pandemic has not affected the habits of the Sundanese people in consuming lalapan.
\end{abstract}

Keywords: botram; eating lalapan; Sundanese society; the COVID-19 pandemic; Tasikmalaya

\section{PENDAHULUAN}

Manusia telah diciptakan dengan penuh keberagaman, terdapat banyak perbedaan, bahkan kondisi kembar sekali pun.
Keberagaman yang ada pada manusia tidak hanya meliputi aspek fisik, namun juga aspek nonfisik. Contoh aspek nonfisik adalah latar belakang, pola pikir, sifat-sifat yang dimiliki 
serta bahasa dan budaya. Keberagamankeberagaman tersebut menjadi keunikan baik untuk setiap manusianya sendiri serta bagi suatu negara yang terbentuk atas kumpulan manusia yang memiliki banyak keberagaman (Mas'udi, 2014).

Indonesia merupakan negara dengan penduduk keempat terbanyak di dunia. Dengan jumlah penduduk yang banyak tersebut, Indonesia memiliki masyarakat yang multikultural, dan didukung oleh kejadian historis yang sangat beragam. Indonesia juga memiliki aspek alam yang sangat luas dan beragam di seluruh penjuru negeri. Akibat halhal tersebut, Indonesia memiliki banyak sekali keberagaman manusia. Keberagaman manusia inilah yang dapat berpotensi menimbulkan kelompok-kelompok dan bentuk struktural yang dapat terbagi-bagi (Ridwan., 2015).

Di antara semua keberagaman itu, salah satu suku yang ada adalah suku Sunda. Suku Sunda adalah suku yang mendiami daerah ujung barat Pulau Jawa hingga daerah Brebes. daerah tersebut sekarang mencakup Provinsi Jawa Barat, Banten, DKI Jakarta, dan sebagian Jawa Tengah. Nama sunda sendiri berasal dari kata Su yang berarti baik. Orang sunda dikenal memiliki sikap yang ramah dan sopan. Hal ini sesuai dengan filosofi hidup orang sunda yaitu Someah Hade ka Semah yang berarti ramah, bersikap baik, menjaga, menjamu, dan membahagiakan tamu atau setiap orang walaupun belum dikenal (Hendriana \& \& Setiyadi, n.d.) (Hidayat \& Hafiar, 2019).

Suku sunda hidup dalam keberagaman budaya yang berpusat di daerah Jawa Barat. Suku sunda merupakan suku kedua dengan populasi terbesar di Indonesia. Oleh karena itu, suku sunda memiliki ciri-ciri kehidupan yang senang dengan bersosialisasi dengan orang lain, memiliki rasa keterlibatan tinggi dengan orang lain, memiliki cukup banyak macam larangan yang disebut dengan pamali, serta memiliki banyak adat istiadat yang cukup kental sehingga masih banyak adat istiadat pada zaman dahulu yang masih dilakukan pada zaman sekarang (Robani, M., 2017).

Pandemi COVID-19 yang berlangsung sejak bulan Maret tahun 2020 di Indonesia memberikan banyak dampak bagi seluruh bagian kehidupan. Pemberlakuan pembatasan sosial berskala besar yang bertujuan untuk mengurangi mobilitas masyarakat dan mengurangi transmisi penyakit tentu membuat banyak aktivitas sosial di luar rumah menjadi terhambat. Hal ini tidak hanya berlaku untuk kegiatan kehidupan sehari-hari, namun juga kegiatan kebudayaan. Salah satu suku yang mungkin terdampak adalah suku sunda.

Suku sunda memiliki banyak kebudayaan yang melibatkan banyak orang. Salah satu budaya yang terkenal adalah budaya botram. Menurut KBBI, botram adalah acara makan bersama yang dilakukan secara santai dan kekeluargaan dengan saling berbagi makanan yang dibawa dari rumah masing-masing. Budaya botram mirip dengan budaya bancakan, hanya saja untuk bancakan makanan yang akan disantap disediakan oleh tuan rumah sedangkan pada botram makanan dibawa dari rumah masing-masing. Botram seringkali dilakukan pada acara-acara tertentu sebagai bentuk rasa syukur kepada Tuhan, terutama sebelum memasuki Bulan Ramadhan yang bertujuan untuk mempererat rasa kekeluargaan. Budaya botram ini menjadi salah satu sarana utama yang membuat masyarakat sunda menjadi masyarakat yang sangat sosialis. Budaya botram sudah cukup terkenal, bahkan hingga di luar masyarakat sunda. Karena budaya botram, masyarakat sunda menjadi masyarakat yang memiliki rasa keterbukaan dan kepedulian tinggi terhadap sesama.

Keunikan lain dari suku sunda yang juga biasa dilakukan sembari melakukan botram adalah budaya makan lalapan. Budaya makan lalapan adalah kebiasaan untuk memakan tumbuh - tumbuhan dalam keadaan mentah. Tumbuh - tumbuhan yang biasa dijadikan lalapan dapat berupa daun - daunan seperti daun singkong, selada; umbi - umbian; buah yang masih muda; bunga; dan biji - bijian. Menurut sejarawan Fakultas Ilmu Budaya (FIB) Unpad Fadly Rahman, budaya makan lalapan sudah dikenal semenjak abad 10M. Budaya lalapan tercatat pada Prasasti Taji dimana disebutkan sebuah nama sajian makanan "Kuluban Sunda" yang berarti lalap. Hingga saat ini, masyarakat selaian sunda pun mengakui bahwa makan lalapan merupakan keunikan yang sangat khas dari suku sunda. Hal ini juga didukung dengan kehebatan masyarakat sunda yang ahli dalam kegiatan bercocok tanam (Asror, 2021) (Hendariningrum, 2018). 
Semenjak adanya pandemi COVID-19, budaya-budaya di Indonesia sangat terpengaruh. Indonesia merupakan negara yang memiliki kebudayaan yang sangat sosialis, hampir semua budaya yang ada tidak mungkin hanya melibatkan satu orang. Rasa sosialis dan kepedulian yang tinggi dalam diri masyarakat Indonesia sudah melekat sejak dahulu. Hal ini bahkan berkaitan dengan sejarah Indonesia berupa kesatuan berbagai daerah yang akhirnya membentuk Indonesia itu sendiri. Karena itu, efek dari pembatasan sosial berskala besar saat pandemik COVID-19 sangat berpengaruh terhadap hampir seluruh kebudayaan yang ada di Indonesia.

Sebagai salah satu suku yang memiliki jangkauan wilayah cukup luas, kebudayaan yang ada di suku sunda tentu juga terdampak. Dengan rasa sosial tinggi yang melekat, masyarakat sunda tentu berkemungkinan mengalami penyesuaian dan perubahan dalam kebudayaan sosial yang setiap hari dialami. Salah dua kebudayaan yang mungkin terdampak pada masyarakat sunda adalah budaya botram dan makan lalapan. Hal ini karena budaya botram biasanya dilakukan secara beramai - ramai dengan sanak saudara. Untuk itu perlu dilakukan penelitian lebih lanjut mengenai dampak pandemi COVID-19 terhadap budaya botram dan makan lalapan. Oleh sebab itu, kami melakukan penelitian untuk mengetahui pengaruh pandemi COVID19 terhadap budaya botram dan makan lalapan.

Budaya botram dan makan lalapan dipilih sebagai bahan penelitian karena kedua budaya tersebut merupakan hal yang sangat erat dengan masyarakat sunda, bahkan di mata suku-suku lain. Kedua budaya tersebut juga mudah dilakukan sehingga harapannya akan mudah untuk dijadikan bahan penelitian. Untuk mendapatkan hasil yang akurat, penelitian dilakukan pada salah satu daerah yang masih kental dengan kebudayaan sunda, yaitu daerah Tasikmalaya. Tasikmalaya merupakan salah satu daerah yang kental dengan kebudayaan sunda. Penelitian ini dilakukan pada daerah yang masih kental dengan kebudayaan sunda karena jika daerah dengan kebudayaan sunda yang masih kental terdampak, maka ada kemungkinan daerah lain yang kebudayaan sundanya sudah tidak terlalu kental akan lebih terdampak. Agar cakupan penelitian tidak terlalu luas, penelitian diberi batasan berupa mahasiswa ITB yang berasal dari Tasikmalaya. Selain dengan melakukan survei terhadap mahasiswa ITB yang berasal dari Tasikmalaya, dilakukan juga studi literatur untuk mendukung data - data yang diperoleh dari survei.

Penelitian ini diharapkan dapat memberikan gambaran kecil mengenai nasib kebudayaan-kebudayaan yang ada di masyarakat sunda selama pandemi COVID-19 berlangsung. Penelitian ini juga diharapkan mampu menginisiasi lebih mengenai penelitian dan perhatian masyarakat terhadap nasib budaya-budaya yang ada di Indonesia.

\section{METODE}

Penelitian ini dilakukan dengan metode penelitian kualitatif dan kuantitatif deskriptif. Beberapa pertanyaan terkait dengan penelitian akan ditanyakan kepada responden. Pertanyaan yang ditanyakan ada yang berupa pertanyaan terbuka sehingga jawaban dari para responden sangat bebas dan bersifat kualitatif. Pertanyaan lain dibuat berbentuk pilihan berganda sehingga dapat diambil persentase angka yang bersifat kuantitatif dan menunjukan kecenderungan kondisi dari para responden secara eksak.

Langkah-langkah dari penelitian ini adalah sebagai berikut.

1. Pembuatan form pertanyaan berdasarkan riset kebutuhan,

2. Pengajuan form kepada calon responden,

3. Analisis data dan studi literatur untuk mengonfirmasi kebenaran data,

4. Pembuatan kesimpulan.

Data penelitian akan diambil dari survei kepada mahasiswa ITB aktif angkatan 2018, 2019, dan 2020 yang berasal dari Kota dan Kabupaten Tasikmalaya dengan pemilihan responden secara acak. Survei dilakukan secara online menggunakan media google form. Pertanyaan-pertanyaan yang diberikan dalam survei adalah sebagai berikut.

1. Identitas, meliputi usia, asal dari kota/kabupaten, dan jenis kelamin

2. Apakah kamu mengetahui tentang budaya Botram?

3. Seberapa sering kegiatan botram dilakukan sebelum dan setelah 
pandemi muncul (dihitung berapa kali dalam 1 minggu)?

4. Apakah dalam kegiatan botram disediakan lalapan? Pada sebelum pandemi dan setelah pandemi muncul?

5. Apakah kegiatan botram harus tetap dijaga kelestariannya selama pandemi berlangsung?

6. Solusi agar kegiatan botram tetap ada selama pandemi

7. Apakah kamu mengetahui tentang lalapan?

8. Apa manfaat lalapan yang kamu ketahui?

9. Apakah dengan adanya pandemi membuat kamu khawatir untuk mengonsumsi lalapan?

10. Seberapa sering kamu mengonsumsi lalapan sebelum dan setelah pandemi muncul (dihitung berapa kali dalam 1 minggu)?

11. Apakah dengan mengonsumsi lalapan menurut kamu dapat membantu menjaga daya tahan tubuh selama pandemi?

12. Berikan alasan kenapa lalapan penting untuk menjaga daya tahan tubuh selama pandemi

Selain itu, dilakukan juga studi literasi dari jurnal-jurnal yang berkaitan dengan topik penelitian. Topik-topik yang berkaitan dengan penelitian ini adalah mengenai kebudayaan Indonesia di tengah pandemi dan kondisi masyarakat sunda.

\section{PEMBAHASAN}

Pembahasan pada penelitian ini diawali dengan hasil survei online yang dilakukan. Survei yang dilakukan melalui media google form kepada mahasiswa ITB angkatan 2018, 2019, dan 2020 yang berasal dari daerah Tasikmalaya memberikan data yang cukup menggambarkan kondisi budaya botram dan makan lalapan di daerah Tasikmalaya. Survei ini berhasil mendata 72 mahasiswa dari total 79 mahasiswa ITB angkatan 2018, 2019, dan 2020 yang berasal dari daerah Tasikmalaya. Dari total 72 mahasiswa tersebut, sebanyak 61 mahasiswa berasa dari kota dan 11 orang berasal dari kabupaten. Kami juga menyurvei identitas mengenai jenis kelamin dari pada responden. Didapatkan data bahwa 41 mahasiswa berjenis kelamin perempuan dan 31 mahasiswa berjenis kelamin laki-laki.

Pertama, untuk riset mengenai budaya botram, didapatkan data bahwa 71 mahasiswa dari total 72 yang mengisi survei mengetahui mengenai budaya botram. Hal ini menunjukan bahwa budaya botram sudah diketahui dengan baik oleh hampir seluruh mahasiswa ITB yang berasal dari daerah tasikmalaya. Lalu, perbandingan jumlah kegiatan botram dalam satu minggu yang dilihat atau dilakukan oleh para mahasiswa responden sebelum dan selama pandemi COVID-19 adalah sebagai berikut.

Gambar 1. Jumlah Kegiatan Botram dalam Satu Minggu

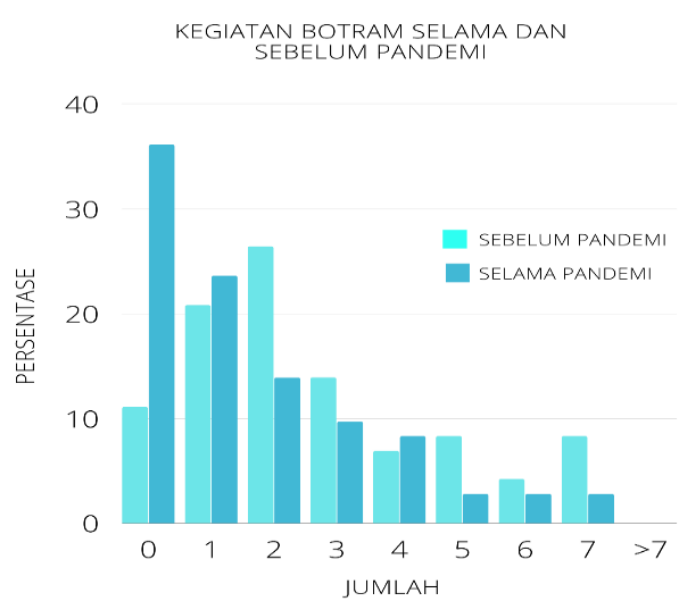

Jumlah kegiatan botram dalam satu minggu pada daerah Tasikmalaya yang diamati oleh para mahasiswa ITB mengalami perubahan sebelum dan selama pandemi COVID-19 berlangsung. Sebelum pandemi, kegiatan botram terlihat paling banyak 1-2 kali dalam satu minggu. Namun, ketika pandemi berlangsung kegiatan botram mengalami penurunan sehingga terlihat banyak responden yang menjawab nol dalam satu minggu. Hal ini menunjukan kesimpulan awal bahwa pandemi menyebabkan aktivitas budaya botram semakin menurun, walaupun tidak sampai hilang.

Responden juga memberikan solusi mengenai kegiatan botram selama pandemi. Banyak responden memberikan solusi berupa pengurangan kegiatan botram dalam satu minggu di lingkungan masyarakat dari yang biasanya bisa mencapai 2 sampai 4 kali dalam satu minggu menjadi cukup satu kali saja. 
Menurut para responden, hal tersebut karena botram satu kali seminggu sudah cukup untuk tetap bisa menjaga tali persaudaraan di antara masyarakat. Beberapa responden juga menambahkan bahwa kegiatan botram harus dilakukan dengan tetap mengikuti protokol kesehatan, yaitu menjaga jarak, membawa makanan sendiri, dan selalu menjaga kesehatan serta tidak berkumpul dalam jumlah yang terlalu banyak. Akan tetapi, beberapa responden merasa bahwa kegiatan botram harus dihentikan dan digantikan dengan kegiatan virtual. Namun, kegiatan virtual justru menghilangkan esensi dari budaya botram yaitu mengobrol dan menyantap makanan secara langsung. Karena itu, solusi paling banyak dan paling tepat untuk tetap mempertahankan budaya botram, terutama di daerah seperti Tasikmalaya yang masih sangat erat dengan kehidupan masyarakat sunda adalah mengurangi jumlah kegiatan botram dan tetap mengikuti protokol kesehatan ketika kegiatan berlangsung.

Budaya selanjutnya yang menjadi bahasan adalah mengenai makan lalapan. Asumsi awal mengenai efek pandemi terhadap budaya makan lalapan adalah akan adanya penurunan jumlah budaya makan lalapan pada masyarakat akibat pandemi COVID-19. Lalapan yang merupakan sayuran segar bisa menjadi media penyebaran virus akibat tidak dimasak terlebih dahulu. Karena itu, kemungkinan akan terjadi penurunan jumlah budaya makan lalapan. Hasil dari survei kepada para mahasiswa ITB adalah sebagai berikut.

Gambar 2. Jumlah Konsumsi Lalapan dalam Satu Minggu

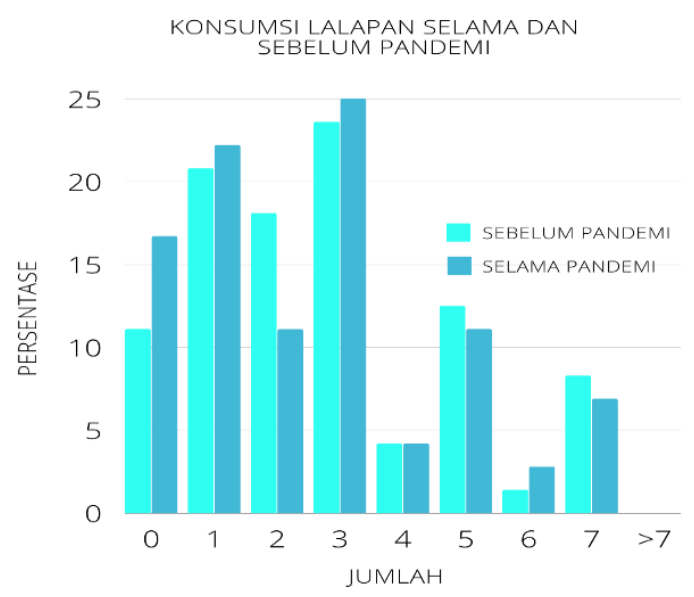

Jumlah konsumsi lalapan sebelum dan setelah pandemi pada responden mahasiswa ITB dari daerah Tasikmalaya tidak berubah. Bisa dilihat bahwa dalam satu minggu, jumlah konsumsi lalapan mayoritas tetap berada di angka 3 kali dalam satu minggu. Lalu, jumlahjumlah lain dalam hasil survei juga tidak mengalami perubahan yang signifikan. Hasil ini kami konfirmasi dengan pertanyaan mengenai keraguan untuk mengonsumsi lalapan selama pandemi. Hasil pertanyaan tersebut adalah 61 dari 72 responden atau sekitar $84.7 \%$ responden merasa bahwa pandemi tidak mempengaruhi mereka untuk tetap mengonsumsi lalapan. Banyak responden yang memberikan opini bahwa lalapan justru dapat membantu meningkatkan daya tahan tubuh karena kondisi sayuran pada lalapan masih dalam keadaan segar.

Riset mengenai konsumsi lalapan ini dihubungkan dengan kegiatan botram. Enam puluh persen responden menjawab bahwa kegiatan botram sebelum dan selama pandemi tetap mengonsumsi lalapan bersama. Artinya, budaya makan lalapan ini tidak terpengaruh oleh adanya pandemi, bahkan tetap dimakan bersama-sama ketika kegiatan botram berlangsung.

Survei yang dilakukan pada penelitian ini terbatas pada cakupan mahasiswa ITB asal daerah Tasikmalaya. Data-data yang ditampilkan ini hanya merepresentasikan sejumlah kecil dari seluruh masyarakat suku sunda di Indonesia. Hasil yang didapatkan dari survei juga tidak separah sampai hilangnya budaya-budaya yang ada mungkin karena survei dilakukan pada daerah Tasikmalaya yang masih erat dengan kehidupan berbudaya sunda. Jika survei dilakukan di daerah lain yang bermasyarakat sunda, mungkin saja akan didapatkan hasil yang berbeda. Namun, hasil survei ini tetap bisa menjadi acuan mengenai keberlangsungan budaya masyarakat suku sunda, yaitu botram dan makan lalapan, ketika pandemi COVID-19 berlangsung. Hasil survei ini juga menunjukan bahwa masih ada daerah di Indonesia yang salah dua budaya suku sundanya masih lestari.

Tidak banyak literatur yang membahas secara spesifik mengenai kebudayaan sunda selama pandemi COVID-19. Hal ini karena akses penelitian yang sulit untuk dilakukan 
selama masa pembatasan sosial berskala besar yang bertujuan untuk mencegan peningkatan kasus penyakit di Indonesia. Namun, pembahasan mengenai kebudayaan di Indonesia secara umum cukup menjadi bahasan yang hangat dikalangan pakar ilmu sosial dan kebudayaan. Banyak pakar berpendapat bahwa perubahan budaya yang terjadi selama pandemi akan tetap mengikuti alur umur yang terjadi ketika terjadi invasi budaya, yaitu transformasi budaya. Sebuah budaya tidak akan bisa sepenuhnya hilang, namun akan beradaptasi sesuai dengan nilai dan kebiasaan yang masih bertahan di masyarakat atau bisa dikatakan bertransformasi (Kistanto, 2018). Budayabudaya tersebut bisa saja masih sama persis dengan bentuk asal, namun bisa juga mengalami perubahan drastic namum masih memegang nilai-nilai utama budaya sebelumnya. Hal ini sebenarnya terbilang wajar, karena pada dasarnya budaya adalah kebiasaan yang dilakukan dan diakui oleh sekelompok masyarakat dalam jangka waktu yang lama.

Perubahan kebudayaan pada masa pandemi bisa jadi juga terjadi pada dua budaya masyarakat sunda yang kita bahas. Menurut data survei yang didapatkan, tidak ada perubahan yang cukup berarti pada budaya makan lalapan. Akses sayuran segar pada berbagai daerah yang memiliki masyarakat sunda selama pandemi masih sangat baik sehingga besar kemungkinan tidak aka nada hambatan berarti untuk tetap mengonsumsi lalapan.

Berbeda dengan makan lalapan, budaya botram sebagai salah satu sarana utama masyarakat sunda melakukan sosialisasi sangat terhambat selama pandemi. Perubahan yang cukup signifikan pada daerah Tasikmalaya yang masih kental dengan kebudayaan sunda menjadi salah satu pertanda bahwa persoalan mengenai budaya ini penting untuk diperhatikan. Jika kita melihat dari solusi-solusi terbanyak yang muncul pada hasil survei, budaya botram tetap harus dilestarikan namun harus disesuaikan dengan protokol kesehatan. Akibat dari hal ini, jumlah kegiatan botram yang awalnya bisa dilakukan setiap hari akan mengalami penurunan jumlah jika kita hitung dalam satuan waktu minggu.
Ketika pandemi telah selesai, akan ada kemungkinan bahwa jumlah botram yang terjadi di masyarakat akan turun, namun tetap sama seperti saat pandemi. Rasa individualis dan rasa ingin mempertahakan kesehatan diri dari orang luar tentu tetap bisa melekat pada masyarakat. Namun, bisa jadi kemungkinan tersebut tidak terjadi. Hal ini didukung oleh rasa sosial tinggi yang memang sejak awal menjadi ciri khas masyarakat sunda. Pada dasarnya, masyarakat Sunda merupakan masyarakat yang sangat sosial dan akrab dengan lingkungan tempat tinggal mereka. Selama tidak ada kondisi yang mengubah lingkungan sekitar secara signifikan, budaya-budaya sosial yang ada pada masyarakat Sunda akan tetap bertahan (Indrawardana, 2013).

Penelitian mengenai efek pandemi terhadap budaya botram masih memerlukan riset lebih lanjut. Riset lanjutan harus dilakukan pada saat pandemic telah usai untuk melihat lebih rinci apakah ada atau tidak perubahan berarti pada budaya botram di masyarakat sunda. Hal ini sekaligus mengonfirmasi mengenai bentukan nilai-nilai yang ada pada masyarakat sunda.

\section{SIMPULAN}

Masyarakat suku sunda, khususnya di daerah yang masih kental dengan kebudayaan seperti Tasikmalaya, sangat erat dengan kebersamaan di masyarakat. Kebersamaan tersebut melahirkan budaya botram, yaitu budaya kumpul dan menyantap makanan bersama. Pandemi COVID-19 yang mengharuskan masyarakat untuk saling menjaga jarak tentu bisa berdampak terhadap budaya botram. Berdasarkan riset yang dilakukan pada mahasiswa ITB asal daerah Tasikmalaya, terdapat penurunan jumlah kegiatan botram yang terlihat di masyarakat selama pandemi berlangsung. Walaupun begitu, tetap ada masyarakat yang melaksanakan botram, namun tidak sesering sebelum pandemi dan harus tetap mengikuti protokol kesehatan.

Masyarakat suku sunda juga terkenal dengan kebiasaan mengonsumsi lalapan atau sayuran segar. Asumsi pada awal penelitian adalah akan ada penurunan jumlah konsumsi lalapan karena khawatir jika konsumsi makanan yang belum dimasak akan meningkatkan kemungkinan terkena penyakit. 
Namun, hasil survei yang didapatkan menunjukan bahwa jumlah konsumsi lalapan dalam satu minggu tidak berubah ketika sebelum dan selama pandemi. Hal ini dikonfirmasi dengan kegiatan makan lalapan yang tetap ada dalam kegiatan botram selama pandemi berlangsung.

Penelitian ini dilakukan hanya pada mahasiswa-mahasiswa ITB asal daerah Tasikmalaya sehingga hanya merepresentasikan sejumlah kecil dari seluruh masyarakat sunda di Indonesia. Namun, penelitian ini tetap bisa menjadi acuan mengenai kondisi budaya suku sunda selama pandemi COVID-19 berlangsung. Penelitian ini juga menunjukan masih ada daerah suku sunda yang budayanya tetap lestari selama pandemi.

Studi pustaka pada penelitian ini memberikan informasi mengenai adanya perubahan nilai-nilai dan bentukan budaya di Indonesia. Mengenai dua budaya pada masyarakat sunda yang menjadi fokus utama penelitian ini, budaya botram merupakan budaya yang mungkin saja mengalami perubahan. Ada kemungkinan bahwa penurunan jumlah botram pada saat pandemi akan menetap ketika pandemi telah selesai. Namun, kemungkinan tersebut bisa jadi tidak terjadi karena rasa sosial yang sudah sangat melekat pada masyarakat sunda. Melihat kemungkinan yang belum pasti, dibutuhkan riset lanjutan untuk mengonfirmasi mengenai ada atau tidak perubahan pada budaya botram di masyarakat sunda akibat pandemi.

\section{DAFTAR PUSTAKA}

Asror, D. (2021). Sejarah budaya lalapan dalam masyarakat sunda. https://ketik.unpad.ac.id/posts/1927/sejar ah-budaya-lalapan-dalam-masyarakatsunda

Hendariningrum, R. (2018). Budaya dan komunikasi kesehatan (Studi pandangan kesehatan pada masyarakat sunda dalam tradisi makan lalapan). Jurnal Lugas, 2(1), 13-19.

Hendriana, H., \& \& Setiyadi, R. (n.d.). Budaya Sunda.

https://dosen.ikipsiliwangi.ac.id/wpcontent/uploads/sites/6/2019/01/BUDAY A-SUNDA-Fungsi-dan-sejarahsunda.pptx

Hidayat, D., \& \& Hafiar, H. (2019). Nilai - nilai budaya someah pada perilaku komunikasi masyarakat sunda. Jurnal Kajian Komunikasi, 7(1), 84-96.

Indrawardana, I. (2013). KEARIFAN LOKAL ADAT MASYARAKAT SUNDA DALAM HUBUNGAN DENGAN LINGKUNGAN ALAM. Jurnal Komunitas.

Kistanto, N. (2018). TRANSFORMASI SOSIAL-BUDAYA MASYARAKAT INDONESIA. Sabda: Jurnal Kajian Kebudayaan, 13(2), 169-178.

Mas'udi. (2014). Historiografi keberagaman manusia (analisis etnografis perjalanan keberadaan manusia). Jurnal Fikrah, 2(1), $1-18$.

Ridwan. (2015). Problematika keragaman kebudayaan dan alternatif pemecahan (perspektif sosiologi). Jurnal Madaniyah, 2(9), 254-270.

Robani, M., L. (2017). Dialektika tafsir alQur'an dan budaya sunda dalam tafsir rawdat al-'Irfan fi ma'rifat al-Qur'an karya Ahmad Sanusi. UIN Sunan Ampel Surabaya. 